Acta vet. scand. 1971, 12, 220-229.

From the Department of Animal Husbandry and Genetics, Veterinary College of Norway, Oslo.

\title{
EFFECTS OF PHYSICAL STRESS ON SERUM ENZYMES AND OTHER BLOOD CONSTITUENTS IN SHEEP
}

\section{By}

\author{
S. Tollersrud, B. Baustad and K. Flatlandsmo
}

The effects of physical exercise on different blood constituents have been more thoroughly investigated in man and laboratory animals than in domestic animals. It has been shown that strenuous physical activity, in untrained individuals particularly, can influence several blood components quite strongly.

The present investigation was carried out to see how far stressing factors connected with transfer of sheep from the lowland to mountain pastures would be reflected in changes of serum enzymes, blood minerals, and other components. It was of interest to ascertain, if differences in reaction could be observed in lambs and ewes taken directly from indoor feeding compared with animals which beforehand had been on pasture.

The sheep were transported by lorry for six hrs. and subsequently herded through mountainous terrain for three hrs.

The following serum enzymes were determined: Aspartate aminotransferase (EC 2.6.1.1), alanine aminotransferase (EC 2.6.1.2), lactate dehydrogenase (EC 1.1.1.27) and its five isoenzymes, $\alpha$-hydroxybutyrate dehydrogenase, and alkaline phosphatase (EC 3.1.3.1). Further were determined the concentrations of calcium, inorganic phosphorus, magnesium, blood sugar, total serum proteins, and haemoglobin.

\section{MATERIAL AND METHODS}

\section{Animals}

Of the 37 animals investigated, nine ewes and six lambs had been turned out to pasture in the middle of May. The remaining 
10 ewes and 12 lambs were fed indoors until the day of the journey, June 27th. The lambs were at this time eight to 10 weeks old, the mean live weights of the indoor lambs being $22 \mathrm{~kg}$ and of outdoor lambs $18 \mathrm{~kg}$. All the ewes, of which some were gimmers, were control animals in experimental studies of intestinal parasites, and were clinically healthy.

The indoor feeding during the last six weeks had consisted only of hay and relatively large amounts of concentrates, the lambs having had access to the concentrate mixture.

\section{Blood sampling, transportation, and herding}

All animals were bled in the evening before departure. They were transported $254 \mathrm{~km}$ in a double-decked lorry, closely packed, from 9 p.m. to 3 a.m. The last two hrs. of transport took place on a rather bumpy and winding mountain road. After unloading a second blood sample was taken, and the 3-hrs. journey on foot was begun. The animals were herded in a moderate speed, but without rest and with little access to grass. The altitude was about $1,200 \mathrm{~m}$ above sea level. During herding some of the animals showed signs of exhaustion, and two lambs had to be carried for long distances. A third blood sample was taken at the end station. Samples from the second and third collections were put in a thermobag with ice, centrifuged in the forenoon, and kept in a refrigerator overnight.

\section{Analytical procedure}

The following serum enzymes were determined according to the procedures of the Sigma Chemical Company, St. Louis, USA: Aspartate aminotransferase (AspAT $=\mathrm{GOT}$ ), and alanine aminotransferase $(\mathrm{AlAT}=\mathrm{GPT})$ as described in Sigma Technical Bulletin No. 505 (1964). The activity is expressed as Sigma-Frankel (S-F) units per ml. $\alpha$-hydroxybutyrate dehydrogenase (HBD) as outlined in Sigma Technical Bulletin No. 495 (1964), expressed as Sigma units of HBD. Total lactate dehydrogenase (LDH) according to Sigma Technical Bulletin No. 500 (1960), expressing the results in Berger-Broida (B-B) units. Isoenzymes of $\mathrm{LDH}$ were determined electrophoretically as described by Baustad \& Tollersrud (1969), the fractions $\mathrm{LDH}_{1}$ to $\mathrm{LDH}_{5}$ in order from the anode.

Alkaline phosphatase was determined according to the procedure of Bessey et al. (1946), the activity expressed as Bessey-Lowry (B-L) units per ml.

Calcium, magnesium and blood sugar were determined in plasma by autoanalyzer technique: calcium according to the procedure de- 
scribed by Halse (1967), magnesium by the method of Gitelman et al. (1966), and blood sugar according to the modification of Hoffmann (1937) described in the Technicon autoanalyzer manual.

Inorganic phosphorus was determined in serum according to a modification (Zeiss-Opton 1951) of the method of Fiske \& Subbarow (1925), total serum proteins by the biuret method, and haemoglobin according to the cyanmethaemoglobin method.

The analytical data were treated statistically by computer technique to test the significance of differences between groups of animals and between times of sampling (Student's t-test).

\section{RESULTS}

The main results are given in Tables 1 and 2. The sheep fed indoor until the day of journey are in the following termed "indoor" animals, while those taken from pasture are called "outdoor" animals.

It appears from the tables that increasing values of most serum enzymes could be observed during transportation and the subsequent herding. The elevation, which varied between groups, was much more pronounced in "indoor" lambs than in other animals. Significant increases from the initial levels were thus found in aspartate aminotransferase, $\alpha$-hydroxybutyrate dehydrogenase, and total lactate dehydrogenase. An average increase of about $50 \%$ was recorded in serum activity of these enzymes at the last sampling. The isoenzymes $\mathrm{LDH}_{3}$ and $\mathrm{LDH}_{4}$ were also significantly raised, the $\mathrm{LDH}_{4}$ fraction in "indoor" ewes as well.

The changes in blood minerals were most distinct after the second bleeding. Highly significant decreases were then observed in phosphorus and magnesium concentrations of the lambs. The values tended to normalize during the walk. Blood sugar showed a continuous, significant increase in "indoor" lambs, while total serum protein was significantly lowered at the end of the journey.

Animals showing symptoms of fatigue and exhaustion during the mountain herding, mainly five ewes and four lambs, all belonged to the "indoor" groups. A comparison of blood values of the laggards with their more unaffected group mates indicated that the greatest changes had occurred in the former animals, particularly in the lambs.

Two lambs and four ewes of the heavily stressed animals showed varying degrees of haemolysis. This was observed in serum from the same individuals at the second and third sampling. Since serum enzyme activities of the respective ewes were 


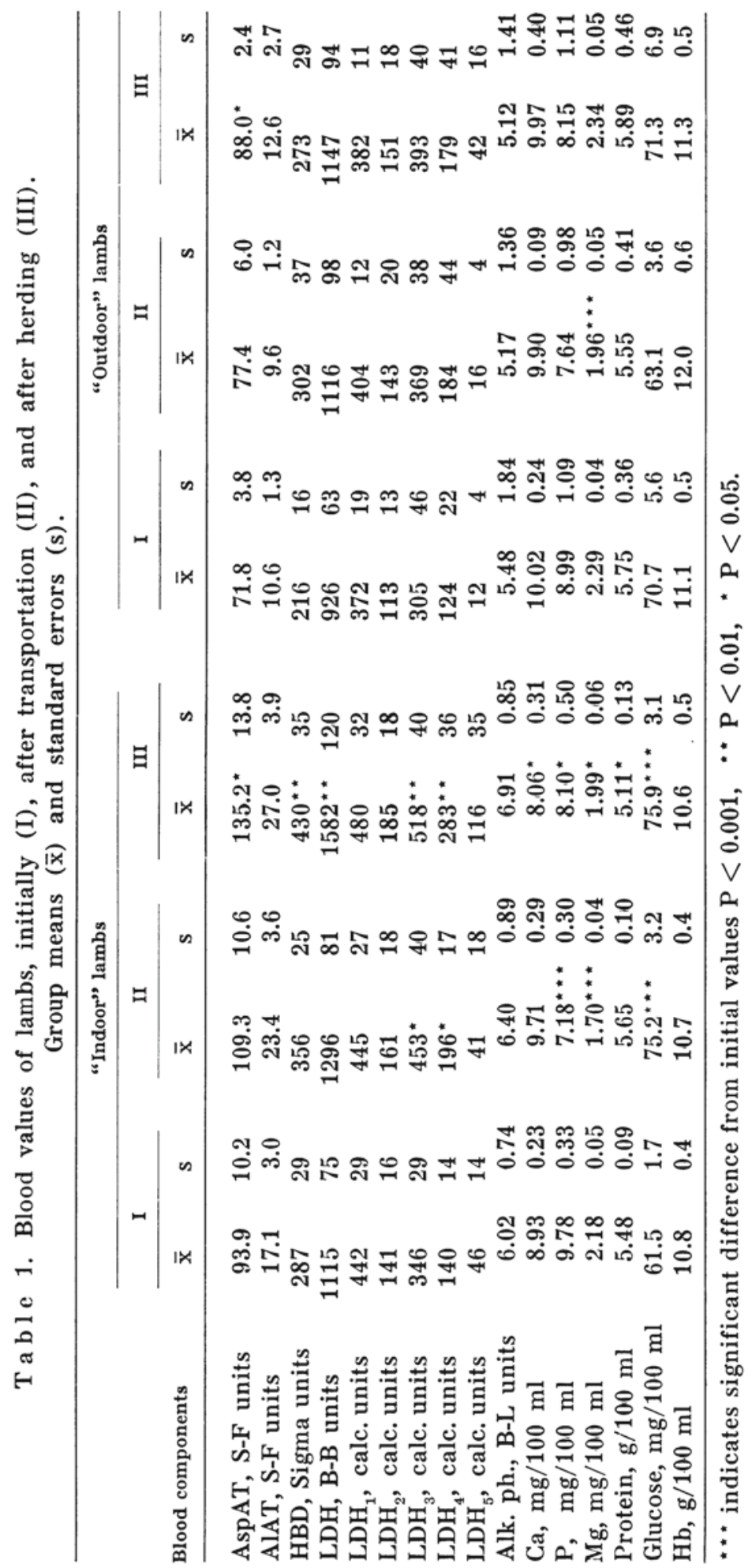




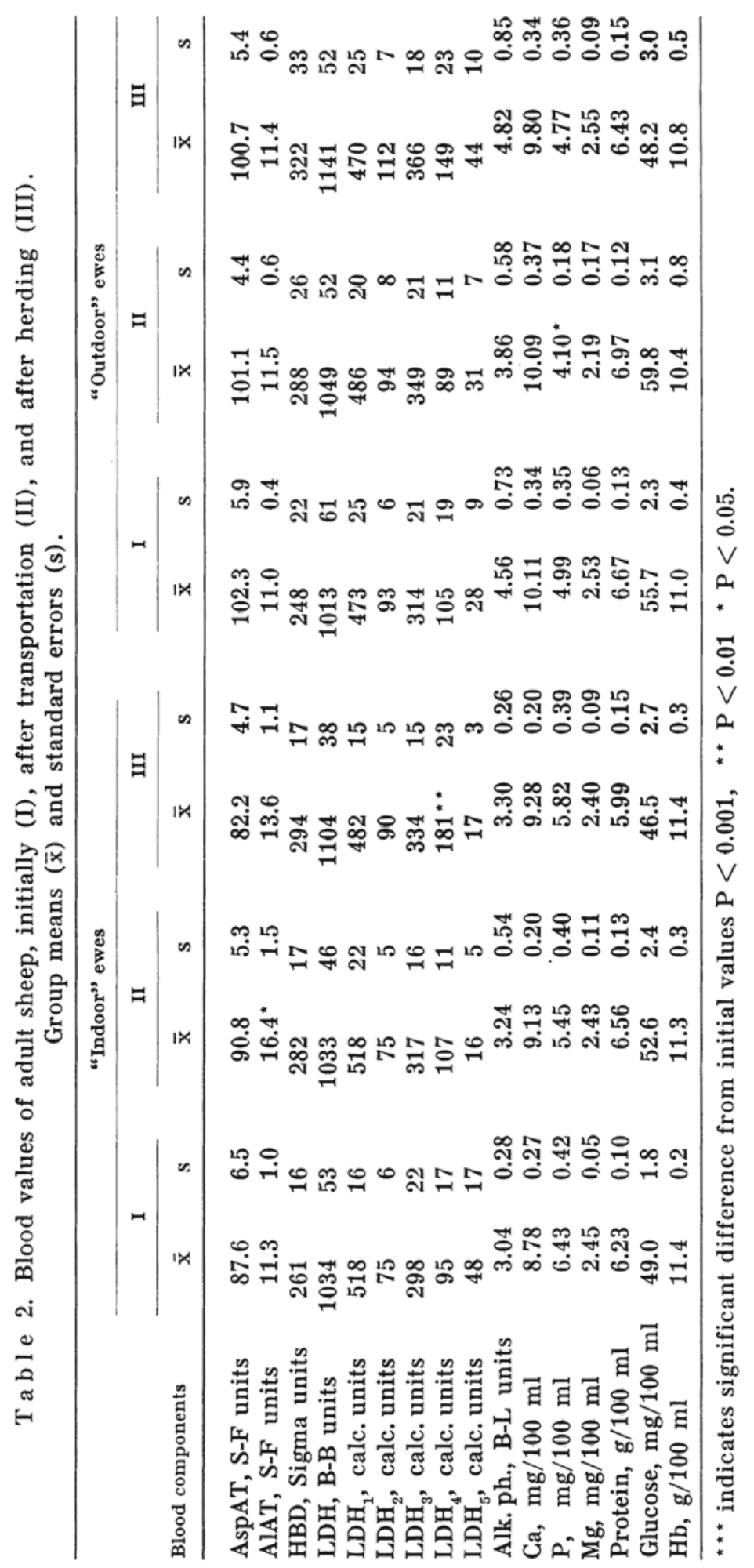


changed very little, it is assumed that the elevated values of the lambs were due to factors other than the haemolysis.

Of interest, but not directly shown in the tables, are the following significant differences between groups at the initial stage:

Aspartate aminotransferase was higher in ewes than in lambs. This was found in animals on pasture, but not on indoor feeding. The observation may support previous findings of an increased serum transferase activity in grazing animals (Tollersrud \& Gedde-Dahl 1971). The percentage fraction of $\mathrm{LDH}_{1}$ was lower, and of $\mathrm{LDH}_{2}$ and $\mathrm{LDH}_{4}$ higher in lambs than in ewes, indicating that the adult LDH isoenzyme pattern was not yet attained in lambs at this age.

Alkaline phosphatase, inorganic phosphorus, and blood sugar levels were higher, while magnesium and total serum proteins were lower in lambs than in adult ewes. Animals fed indoors showed lower calcium and higher phosphorus concentrations than those on pasture.

\section{DISCUSSION}

It is generally believed that an elevated enzyme activity in blood serum after physical excercise is due to an increased cellular membrane permeability. The permeability has been shown to increase under the influence of factors such as hypoxia, insulin, and adrenal hormones (Hess 1963). Physical exercise at simulated high altitudes has caused greater serum enzyme elevations than at sea level (Altland et al. 1968). How far and in what way endocrine systems are involved in the enzyme release from cells to blood is not fully known. The following mechanism may be possible: Stress $\rightarrow$ endocrine reaction $\rightarrow$ increased cellular permeability $\rightarrow$ enzyme release.

Cell damage in the usual sense as a cause of enzyme leakage seems to be less probable under these circumstances, since recovery to normal levels usually occurs within a few hrs. after cessation of the physical load (Halonen \& Konttinen 1962).

In the present observations it was clearly demonstrated that the greatest serum enzyme increase appeared in lambs which were unaccustomed to muscular activity. The obvious shift of LDH isoenzyme distribution in serum towards a pattern more rich in intermediate and cathodic fractions points to the assumption that the main origin of enzyme release would be ske- 
letal muscle. As earlier shown (Tollersrud 1970) skeletal muscle tissue of sheep is more rich in cathodic LDH isoenzymes than any of the other main organs. A significant increase of the $\mathbf{L D H}_{5}$ fraction, however, was not obtained, partly due to great individual variations within the group. $\mathrm{LDH}_{5}$ is considered to be the most labile of the $\mathrm{LDH}$ isoenzymes, in vivo as well as in vitro.

Hyldgaard-Jensen (1967) reports a clear tendency towards increased appearance of the cathodic LDH isoenzymes in plasma obtained from pigs just before killing at the slaughter-house compared with samples taken at the farm.

Observations by Manz (1964) of slaughter-pigs showed an increased total LDH activity with increasing distances of transportation. Prange et al. (1966) found, in cattle, serum elevations of LDH attributable to transport. Young animals appeared more sensitive in this respect than older ones.

Initial levels of serum enzymes and LDH isoenzymes of adult sheep are in agreement with data reported earlier (Tollersrud 1969, Tollersrud 1970). The present values of total LDH and $\mathrm{LDH}$ isoenzymes in the lambs differ, however, from the results previously obtained in newborn and in 10-day-old lambs (Tollersrud \& Baustad 1970). LDH and its isoenzyme fractions in serum of sheep obviously depend greatly upon the age of the animals, as shown in the following summary of previous and present results in Table 3 .

T a b l e 3. Total LDH and LDH isoenzymes of sheep at different ages.

\begin{tabular}{|c|c|c|c|c|c|c|}
\hline \multirow{2}{*}{ Age } & \multirow{2}{*}{$\begin{array}{l}\text { Total } \\
\text { LDH }\end{array}$} & \multicolumn{5}{|c|}{ Percentage and calculated values of LDH isoenzymes } \\
\hline & & $\mathrm{LDH}_{1}$ & $\mathrm{LDH}_{2}$ & $\mathrm{LDH}_{3}$ & $\mathrm{LDH}_{4}$ & $\mathrm{LDH}_{5}$ \\
\hline 10 hrs. & 1530 & $23.1(353)$ & $12.9(197)$ & $41.1(628)$ & $23.0(352)$ & $0(0)$ \\
\hline 10 days & 1452 & $29.5(428)$ & $16.6(241)$ & $35.8(520)$ & $18.1(263)$ & $0(0)$ \\
\hline 10 weeks (indoor) & 1115 & $39.6(442)$ & $12.7(141)$ & $31.0(346)$ & $12.6(140)$ & $4.1(46)$ \\
\hline Adults (indoor) & 1034 & $50.1(518)$ & $7.3(75)$ & $28.8(298)$ & $9.2(95)$ & $4.6(48)$ \\
\hline
\end{tabular}

Total LDH and the intermediate isoenzyme fractions of physically stressed lambs showed a trend towards values previously observed in younger lambs.

The causal factor of haemolysis in some of the heavily stressed animals is not known. The considerable fall occurring in magnesium and inorganic phosphorus concentrations during the transport, may be contributing factors to the collapse in 
some of the "indoor" animals, and to cases of tetany seen in previous years. The most critical period is empirically shortly after the start of herding, coinciding with the lowest observed blood mineral levels. Calcium injections have proved to be of little effect. This may be in accordance with the present results, showing that blood calcium levels were not decreased after the transportation.

The investigation supports previous practical experiences saying that well-fed animals taken directly from indoors are more susceptible to physical break-down during transfer to the mountains than those previously acclimatized on pasture.

\section{ACKNOWLEDGMENTS}

The authors wish to express their thanks to Mr. Karl Halse, Department of Physiology, for performing analyses of some of the blood components, and to Mr. Oddvar Helle, Department of Internal Medicine, Parasitology Section, whose cooperation made the investigation possible.

\section{REFERENCES}

Altland, P. D., B. Highman \& B. Dean Nelson: Serum enzyme and tissue changes in rats exercised repeatedly at altitude: Effects of training. Amer. J. Physiol. 1968, 214, 28-32.

Baustad, B. \& S. Tollersrud: Isoenzymes of lactate dehydrogenase in swine. Stability during storage at different temperatures and by heat treatment. Acta vet. scand. 1969, 10, 372-381.

Bessey, D. A., O. H. Lowry \& M. J. Brock: A method for the rapid determination of alkaline phosphatase with five cubic millimetres of serum. J. biol. Chem. 1946, 164, 321-329.

Fiske, C. H. \& Y. Subbarow: The colorimetric determination of phosphorus. J. biol. Chem. 1925, 66, 375-400.

Gitelman, H. J., C. Hurt \& L. Lutwale: An automated spectrophotometric method for magnesium analysis. Analyt. Biochem. 1966, 14, 106-120.

Halonen, P. I. \& A. Konttinen: Effect of physical exercise on some enzymes in the serum. Nature (Lond.) 1962, 193, 942-944.

Halse, K.: Automated photometric estimation of blood calcium. Titration of zinc by calcium from $\mathrm{Zn}$-EGTA in the presence of a zinc indicator. In Automation in Analytical Chemistry. Technicon Symposia 1967. Mediad Inc. White Plains N.Y. 1968.

Hess, B.: Enzymes in Blood Plasma. Academic Press. New York and London 1963.

Hoffmann, W. S.: A rapid photoelectric method for the determination of glucose in blood and urine. J. biol. Chem. 1937, 120, 51--55. 
Hyldgaard-Jensen, J.: The influence of blood-sampling technique on lactic dehydrogenase $(\mathrm{LDH})$ in pig plasma. Acta vet. scand. $1967,8,83-85$.

Manz, D.: Der Einfluss der Belastungen auf den Gehalt an LDH im Serum von Schlachtschweinen. (The influence of stress on LDH in serum of slaughter-pigs). Dtsch. tierärztl. Wschr. 1964, 71, $597-601$.

Prange, H., E. Kolb, E. Grün \& H. Gürtler: Über den Einfluss einer Transportbelastung auf die Aktivität der Laktatdehydrogenase im Serum von Rindern. (The influence of transport on lactate dehydrogenase activity in serum of cattle). Arch. exp. Vet.Med 1966, 20, 399-409.

Tollersrud, S.: Stability of some serum enzymes in sheep, cattle, and swine during storage at different temperatures. Acta vet. scand. 1969, 10, 359-371.

Tollersrud, S.: Heat stability of serum lactate dehydrogenase and its isoenzymes in young and adult cattle and sheep. Evaluation of a relative heat stability test and serum determination of $\alpha$-hydroxybutyrate dehydrogenase in diagnostic work. Acta vet. scand. $1970,11,510-524$.

Tollersrud, $S$. \& B. Baustad: Serum enzyme activity of newborn calves, pigs, and lambs. Acta vet. scand. $1970,11,525-535$.

Tollersrud, S. \& T. W. Gedde-Dahl: Diurnal and seasonal variations of serum enzyme activity in cattle and sheep. Acta vet. scand. 1971, 12. In press.

Zeiss-Opton: Klinische Photometrie. (Clinical photometry). 3. Aufl. Stuttgart 1951.

\section{SUMMARY}

In connection with transfer of sheep from the lowland near Oslo to mountain pastures at an altitude of $1,200 \mathrm{~m}$ above sea level, investigations were carried out in 37 animals to study the effect of physical stress on serum enzymes and other blood constituents. The sheep were adult ewes and lambs. About half of the animals had been accustomed to outdoor life on pasture for more than one month, while the others were moved directly from indoor feeding. Blood was collected before departure, after six hrs. of long-distance transportation by lorry, and after three hrs. of subsequent continuous herding on foot. The following blood components were determined: Aspartate aminotransferase (AspAT $=$ GOT), alanine aminotransferase (AlAT $=$ GPT), $\alpha$-hydroxybutyrate dehydrogenase (HBD), total lactate dehydrogenase $(\mathrm{LDH}), \mathrm{LDH}$ isoenzymes, alkaline phosphatase, calcium, inorganic phosphorus, magnesium, blood sugar, total serum proteins, and haemoglobin.

In summary, it may be said that the lambs reacted with greater changes of the blood components than adult animals, and that untrained, indoor fed lambs were distinctly more sensitive than those 
taken from pasture. The "indoor" lambs showed a statistical significant increase from the initial values in AspAT, HBD, total LDH, the isoenzymes $\mathrm{LDH}_{3}$ and $\mathrm{LDH}_{4}$, and blood sugar. Significantly decreased values were recorded in $\mathrm{Ca}, \mathrm{P}, \mathrm{Mg}$, and total serum protein. Some of these changes, as in $\mathrm{Mg}$ and $\mathrm{P}$, were most pronounced after transportation, while elevations of serum enzyme levels continued to increase during the subsequent herding.

Based upon the shift in $\mathrm{LDH}$ isoenzyme distribution towards a more cathodically dominated pattern it is supposed that the main origin of increased serum enzyme activity was skeletal muscle.

\section{SAMMENI)RAG}

Virkningen av fysisk påkjenning på serumenzymer og andre blodbestanddeler hos sau.

I forbindelse med fjellsending av sau fra Oslo-området til Iungsdalen i Hallingdal, 1200 m.o.h., er det utført blodanalyser på 37 dyr for å unders $\emptyset \mathrm{ke}$ virkningen av fysisk stress på serumenzymer og andre blodkomponenter. Ca. halvparten av dyrene, både voksne og lam, hadde forut for fjellsendingen gått ute på beite i vel en måned, mens de $\varnothing$ vrige ble sendt direkte fra innefóring. Blodprøver ble tatt f $\phi \mathrm{r}$ sending, etter seks timers lastebiltransport og etter en påfølgende tre timers sammenhengende driving.

Følgende blodbestanddeler ble bestemt: Aspartataminotransferase $($ AspAT $=$ GOT $)$, alaninaminotransferase $(\mathrm{AlAT}=\mathrm{GPT}), \alpha$-hydroksybutyratdehydrogenase (HBD), total laktatdehydrogenase (LDH), LDHisoenzymer, alkalisk fosfatase, kalsium, uorganisk fosfor, magnesium, blodsukker, total serumprotein og hemoglobin.

Summarisk kan en si at lammene reagerte med større forandringer i blodkomponentene enn voksne dyr, og at lam som var utrenete, reagerte sterkere enn de som var vant til uteliv på forhånd. Utrenete lam viste en statistisk signifikant $\varnothing \mathrm{kning}$ fra utgangsverdiene i AspAT, HBD, total $\mathrm{LDH}$, isoenzymene $\mathrm{LDH}_{3}$ og $\mathrm{LDH}_{4}$ samt blodsukker. En signifikant nedgang ble funnet i $\mathrm{Ca}, \mathrm{P}, \mathrm{Mg}$ og totalprotein. Noen av disse forandringene, f. eks. $\mathrm{Mg}$ og $\mathrm{P}$, var st $\varnothing \mathrm{rst}$ etter transporten, mens serumenzymnivået fortsatte å stige under den påfølgende driving.

Ut $\mathrm{i}$ fra den observerte forskyvning $\mathrm{i}$ fordelingen av $\mathrm{LDH}$ isoenzymer i serum mot et mer katodisk preget mønster, antar en at opprinnelsen til de for $\varnothing$ kete serumenzymverdier hovedsakelig var skjelettmuskulatur.

(Received March 28, 1970). 